Meta

Journal des traducteurs

Translators' Journal

\title{
Hermeneutics and Ideology: On translating Freud
}

\section{Partick Mahony}

Volume 39, numéro 2, juin 1994

La traduction vue de l'extérieur - Translation: a view from the outside

URI : https://id.erudit.org/iderudit/003538ar

DOI : https://doi.org/10.7202/003538ar

Aller au sommaire du numéro

Éditeur(s)

Les Presses de l'Université de Montréal

ISSN

0026-0452 (imprimé)

1492-1421 (numérique)

Découvrir la revue

Citer cet article

Mahony, P. (1994). Hermeneutics and Ideology: On translating Freud. Meta, 39(2), 316-324. https://doi.org/10.7202/003538ar

\section{Résumé de l'article}

Une traduction éclairée de l'œuvre de Freud présuppose une connaissance toute spéciale des aspects herméneutiques et idéologiques que comporte la tâche. Ceci comprend : la nature même de la langue allemande qui a influencé la transcription verbale particulière par Freud de l'inconscient; les subtilités de son style exploratoire avec ses implications idéologiques; et enfin, sa compréhension complexe de la psychanalyse elle-même. A ce sujet, on peut déceler des déficiences révélatrices de l'édition anglaise des œuvres de Freud, dite Standard Edition, dont la traduction a été dirigée par James Strachey.
Ce document est protégé par la loi sur le droit d'auteur. L'utilisation des services d'Érudit (y compris la reproduction) est assujettie à sa politique d'utilisation que vous pouvez consulter en ligne.

https://apropos.erudit.org/fr/usagers/politique-dutilisation/ 


\title{
HERMENEUTICS AND IDEOLOGY: ON TRANSLATING FREUD
}

\author{
PARTICK MAHONY \\ Université de Montréal, Montréal, Canada
}

\begin{abstract}
Résumé
Une traduction éclairée de l'œuvre de Freud présuppose une connaissance toute spéciale des aspects herméneutiques et idéologiques que comporte la tâche. Ceci comprend: la nature même de la langue allemande qui a influencé la transcription verbale particulière par Freud de l'inconscient; les subtilités de son style exploratoire avec ses implications idéologiques; et enfin, sa compréhension complexe de la psychanalyse elle-même. À ce sujet, on peut déceler des déficiences révélatrices de l'édition anglaise des ouvres de Freud, dite Standard Edition, dont la traduction a été dirigée par James Strachey.
\end{abstract}

According to the linguistic hypothesis of Benjamin Whorf (1942), our conception of the world is largely if not entirely determined by the structure of our mother tongue. Most linguists, however, reject this hypothesis and its strong implications that would radically estrange people: countering the primacy accorded by Sapir and Whorf to the formal properties of language over its content, the objectors declare that human experience is amenable to expression in any language and is not foreclosed by the formal properties of any particular language system. This being stated, we may cautiously proceed to a useful distinction: foreclosure is one thing, facilitation in some measure another. The peculiar structure of a language may in fact lead, though not restrict, native speakers, to conceptualize in certain ways.

With the notion of facilitation in mind, we can appreciate Grubrich-Simitis's speculation that some basic grammatical qualities of the German language "furthered Freud's psychoanalytical thinking and perhaps made it easier for him to adapt linguistically to the dynamics of unconscious and preconscious processes" (1986: 289, my italics)1. To that effect, Grubrich-Simitis refers to various traits of the German language: the many verbforms to express the passive mode, the ready convertibility of the passive sentence into the active and vice versa, and the existence of certain passive forms which actually obscure the notions of active and passive; as well, the flexibility in the German to convert one part of speech into another involves a softening demarcation between verb, noun and adjective, with the result that a primary process flow may be evoked within a strictly maintained secondary process discourse. To this list we might add the vitality of numerous German nouns to mean both activity and the result of that activity (e.g., Erinnerung is remembering and memory; Wunscherfüllung wish-fulfilling and wish-fulfillment; Phantaisie, phantasying and phantasy). One might also allude to the distinctive capacity of German syntax to relate and stress ideas; to the lexical frequency of her and hin in German, which spatially relate utterances to the speaker; and to the wealth of compound nouns whose components may variously interact, thus a lexical construct propitious for condensation and displacement. In a general sense, the phenomenological and dynamic expressivity of German has been strongly underlined ( $c f$. Schotte 1959: 116, 120, 121; 
Malbanc 1968: passim). Said otherwise, the internal dialectics characterizing the German language is a significant part of its facility to render process.

Above and beyond the general subject of the influence of the German language on Freud, there is the more specific one of Freud's use of it, a use somewhat obfuscated by Strachey's translation. That monumental translation, though laudable, presents problems, and as time goes on, evidence increases for one to dispute with Giovacchini (1982: vii), who, after having read Freud's entire works in both German and English, voices a nigh complete acceptance of Strachey's text. As my purpose is to show how the very nature of an enterprise can be changed by translations embedded in and arising out of an entirely different world-view and ideology, my presentation will focus chiefly on various aspects of Freud's discourse which have been distorted by Strachey's translation. My coverage, however, is but partial, and what is more, in keeping with my somewhat associative procedure, the varying number and length of the clarifying examples I supply for demonstration are not determined by their correspondence with the intrinsic importance of the point under consideration. This said, we might best proceed to Strachey's translation if we first stop to orient ourselves by considering in a brief overall fashion Freud's understanding and use of psychoanalytic language, and then the nature of psychoanalysis itself.

Figuring centrally in Freud's writing practice was the way he would understand psychoanalytic language. For him, the language of psychoanalytic theory was out and out a figurative language (Bildersprache) and not a literal one, and more than that, only by means of that distorting figurative language could he know about unconscious processes, not to mention the fact that their distorting nature can never be fully known in the first place. Even after labelling as figurative such psychological terms as drive and ego, he said that the alternate choice of physiological or chemical terms would also involve us in figurative language, albeit one that is long familiar and perhaps simpler $(13: 65) /(18 / 60)^{2}$. But psychoanalysis as Freud could have understood it was bounded by the figurative in its therapeutic as well as its theoretical sphere. Thus, if we turn to the empirical base of psychoanalysis - the clinical setting - we realize how Freud could have conceived the massive presence of language as figurative. That is to say, the central determinant of the patient's associations is transference, whose verbalization is by its very nature figurative. The earlier Freud used to spell this out by calling transference a false connection, hence a kind of relation definable by the past participle of the German word for transference (Übertragung) - übertragen, which also means metaphorical or figurative (1:308-9/2:302-3). (Involved here is an unappreciated psychoanalytic contribution to stylistics: even though a patient may report some casual external event in matter-of-fact literal language, insofar as that report is affected by the transference, it is also figurative, übertragen. Thus, while putting aside the basic metaphorical nature of all language we can nevertheless say that if the patient's story is in figurative language, the transferential phenomenon makes it doubly figurative. The current debate over the place of transference vs. therapeutic alliance must also be seen as a debate over the nature of the patient's language!).

Apart from its inevitability in Freud's theorization, figurative language emerged increasingly in his prose because of the very way he wrote. By and large he composed in an exploratory manner, registering what was already said, ought to be said and was trying to be said; in sum, a fluid investigative discourse attuned to the dynamic nature of psychic activity. This processive quality was central, not peripheral, to his discourse; as such, Freud presented the complexities of the mind and language on the move. The how of saying was also the what; message was inseparable from its form. Freud's discourse may be further understood when we realize that to some degree it anticipated a change in the college freshman curriculum in North America: whereas composition was traditionally 
taught in the past as a means of attaining grammatically and logically sound expression, there is now a shift. College professors in English no longer speak of composition but of writing, and this very writing, rather than being chiefly a technique of communicating, is now seen to be means of inquiry and self-scrutiny, a means of discovering what one thinks and a means of generating meaning rather than of deciding or imposing closure. This writing, to start with, assists the writer to interpret and read, enlarge his horizons, and appreciate the relationship of language to himself, social order and social change.

Part and parcel of Freud's exploratory writing, stress on process and reluctance to closure was his reliance on language that was evocative and tentative. Evocatively, this language smacks of multi-level experiencing: we enjoy its supple feeling tone, its modulations of empathic rapprochement with patient and reader, and its resonant personifications that ward off chilling reification. Intimately bound with Freud's evocativeness was his penchant for the tentative. Given his association of clear, unambiguous concepts with self-indulgent speculative and philosophical systems, he would have subscribed to Popper's tenet that "Every scientific tenet must remain tentative forever" (1965: 280). It follows that Freud strove for an approximative quality in language that was appropriate for psychoanalysis as a developing discipline, for the ultimately unknowable unconscious, for the facilitation of his writing under impulse, and for the stimulation of the reader's conscious and unconscious responses to the text. In line with all this, Freud was wont to use flexible definitions and expositorily favoured the use of vital, everyday German words as most suitable - most suitable not only because "in every language the concrete terms, as a result of their development, are richer in associations than abstract ones" $(2 / 3: 345 / 5: 340)$, but also because of the ever increasing resonance of concrete terms in current life. In that sense, if Schreber had a Grundsprache, a basic language, Freud had one too.

Another aspect of Freud's tentativeness is found in the particular nature of his dialogic appeal, hence engaging his readers to participate with him in an ongoing venture of research. As I have said over the years, Freud's texts have the qualities of a do-it-yourself-kit. For a helpful gloss we can't do better than refer to Freud's essay The Moses of Michelangelo (1914). It is for no ill reason that of the many statues Freud possessed and the thousands more he had seen, the only one he chose to write about at length presents the bearded Moses in "the remainder of a movement that has elapsed" (10:194/14:299) - thus a dynamic spectacle leaving us room to make inferences and in our imagination to fill in the scene of its movement. Then again, Freud's writings are sometimes explicitly dialogic, inviting us to fill out or mentally emend some local passage (13:251-252/19:24-25; $15: 85 / 22: 78-79)$. On a grander scale, we are invited to continue the unending task left by Freud who consistently avoided comprehensiveness in favor of a fragmentary, nomadic discourse.

If Freud's discourse has a democratically participatory element, it also contains a directive rhetorical force that overwhelms the reader. I can bring up no better evidence for this than the following non sequitur, quoted from Strachey's translations of Analysis Terminable and Interminable (1937):

The [woman's] appeased wish for a penis is destined to be converted into a wish for a baby and for a husband, who possesses a penis (S.E. 23:251).

In the original text, however, Freud speaks of the woman's unappeased wish (ungestillten), (16:97). Why then in the countless readings given to Strachey's translation has his glaring error been undetected up to now? We can be assured that the non-sequitur would have been readily spotted if it were cited out of context or if it were written by someone other than Freud. I can attribute the readers' overlooking of the error to its being 
contextually set within the blinding power of Freud's verbal genius. A neglect of this feature by psychoanalysts - which spills over into the way Strachey is interpreted - calls for a history of psychoanalytic styles of reading.

Any adopted style of reading affects our understanding of the nature of psychoanalysis and has attendant implications for translating Freud. In my opinion, this crux about the nature of psychoanalysis will always persist to some degree. It was in the early year of 1895 that Freud attempted to draw up an unadulterated picture of psychoanalysis as a natural science; but shortly after, he abandoned the Project and never resumed it in an uninterrupted way. A modern debate, with terminological confusion of its own, rages as to whether Freud, despite his intentions, developed a clinical theory that was hermeneutic rather than scientific; other times, the debate about the status of psychoanalysis is carried on with minimum reference to Freud. In Loewald's (1980: 5) moderating opinion, psychoanalysis is a therapeutic art, a branch of the humanities, and a natural science, the latter often explicitly claimed by Freud. Bettelheim (1983), however, places Freud squarely within the hermeneutic field although he never uses the term as such, preferring the humanistic label. By contrast, some critics would see Freud as a natural scientist, but differ as to whether metapsychology is essential to the nature of psychoanalysis as a natural science. An added complexity here involves the fact that, as Holt $(1972,1978)$ repeated, the humanistic picture of man underlies much natural science. In the camp of the hermeneutic proponents, on the other hand, differences also obtain: Schafer (1976) would do without metapsychology, but Ricoeur (1965) retains it in his novel description of the unconscious as comprised of a verbal and an energetic discourse. To further our discussion, we might also bear in mind three other considerations: first, Freud himself estimated that he had no talent at all for natural sciences (Jones 1955: 397); second, Freud's conception of the field was broad enough that he called works of applied psychoanalysis, including his own hermeneutic study of Gradiva (1907), as a mixture of exact science and speculation (S.E. 9:248); third, throughout his writings, he often quoted literary authors for approval, but rarely did he quote natural scientists or even physicians unless they had become psychoanalysts (Bettelheim 1982: 38).

What are we to make of all this? Did Freud after 1895 use the terminology of natural science only in an ironical mode, or unreflectively in an inconsistent manner? Another paradigmatic answer is that he employed such terminology non-ironically but yet in a tentative and anticipatory way, hoping that his verbal approximations were lying in wait for a firm biological and chemical base in the future, i.e., that his claims about psychoanalysis as a natural science were a serious aspiration about the future rather than constituted a present realization. Accordingly, Freud would have felt that his physicalistic models, expressed in verbal approximations about the unconscious never to be fully known, added up to an aspiratory gesture within the very development of natural science as a whole.

In one sense we can agree with Wilson (1987: 308) that the notion of a scientific Freud was hardly due exclusively to the influence of the Standard Edition - Freud himself made many explicit claims about his scientific aims in his public and private communications. Yet was Freud's language in the Gesammelte Werke more characteristically alliable to what is known as scientific or as humanistic? A great deal of light has been shed on that necessary question from an ongoing research of primary source texts, the results of which are in part the following. Early on in this century, a combination of political, economic and other ideological motives guided Jones in his programme for translating Freud, a programme that together with its subsequent elaborations greatly influenced Strachey's translation. Ideology underlay Jones's advocacy of a true, uniform and definitive psychoanalytic terminology; thus, a monosemic reduction of Freud's texts that, in 
Jones's mind, would serve as a most efficient tool in the institutionalization of psychoanalysis (see Steiner 1986 and 1987: passim; 1988 esp. pp. 181-184 and 187-191). Summarily,

a particular interpretation of psychoanalysis [existed] from its inception... Psychoanalysis, for Jones, was a science, a scientific psychology to be related to the other natural sciences, primarily biology and physiology (Steiner 1987: 53).

Thus the designed policy of Jones, Brill and Strachey was to resort to a Latinizing and Graecizing of Freud's language in order that, so ennobled, it would be endowed with greater scientific credibility (Steiner 1986: 110;1987: 80-81). This is not to say of course that the evocative, conversational and Germanic quality of Freud's own language was shorn of Greek or Latin roots (Wilson 1987: 304), but it remains an important question of relative difference between the target and derivative texts. It is also pertinent here to recall the philologists' emphasis that some of our Germanic words in English, contrary to popular conception, may be much longer than ones of classical origins $-c f$. respectively neighborhood (Nachbarschaft) and act (actus in Latin). Rather than belabor this point, we might now shift our general perspectives and turn to scrutinize, in the second section of our essay, some significant details of Strachey's translation.

Leaving technical terms behind, we may still profitably address Freud's processive and tentative language, which in the Standard Edition tended to give way to closure and quiescence. In particular, Strachey was apt to hone down Freud's subtle wording which informed the modest claims in the titles of his works. To select one among many examples, the treatise Neue Folge der Vorlesungen zur Einführung in die Psychoanalyse (1933) might be given as New Series of Lectures toward Introducing Psychoanalysis (Strachey's rendering was New Introductory Lectures on Psychoanalysis). Staying with this treatise, we can appreciate how Freud's processiveness is exemplarily encapsulated in an aphorism, which itself has become a rallying cry for Lacanians with their own particular twist:

Wo Es war, soll Ich werden (G.W. 15:86).

Where id was, ego shall become.

The dynamic quality of become, however, is greatly lessened by Strachey's be (S.E. 22:80).

To exemplify Freud's evocative language, we begin by returning to a title, this time of the metapsychological essay Triebe und Triebschicksale (Drives and Destinies of Drives, 1915). The common term Schicksale (destinies) has a certain deterministic note which is missing in Strachey's jump to an erudite level of language in the second half of his own title: Instincts and Their Vicissitudes. On another score, Strachey's adhesiveness of the libido neutralizes the suggestive effect of Klebrigkeit (11:360-361/16:348), which is more frequently used in the pejorative sense of stickiness. Here, on the other hand, is a specimen of Freud's playful tone as he discusses the serious topic of an analyst's unilateral determination of treatment:

... es bleibt dem Takt überlassen. Ein Missgriff ist nicht mehr gutzumachen. Das Sprichwort, dass der Löwe nur einmal springt, muss recht behalten (G.W. 16:62).

Strachey translates:

... the decision must be left to the analyst's tact. A miscalculation cannot be rectified. The saying that a lion only springs once must apply here (S.E. 23:219).

It's a matter of the linguistic limits of English that our word tact gives but one sense of the German Takt, whose other meaning points to musical time or measure. 
Strachey's miscalculation in the present context does not fully reflect the German Missgriff, whose literal translation by erroneous grasp looks forward to the kinesthetic notes of the following sentence: "The saying that the lion springs only once necessarily takes hold here" (must recht behalten - rendered more abstractly by Strachey as must apply here). In the light of the previous examples, it might be timely for me to pause at this point and insist that my purpose is not to indulge in a denigration of Strachey. Given the fact that Freud as translator paid much more attention to ideas than to words (PollakCornillot 1986), it is quite likely that Strachey paid more attention to the signifier than did Freud as translator.

Deserving a special mention by itself is that kind of evocativeness that arises from Freud's repeatedly folding metalanguage back into language and undercutting the difference between them; by far, the more significant instances of this practice are those that are not limited to a passage but echo throughout a whole work. A choice example of this is The Interpretation of Dreams, whose expository progress is described by Freud as journeying through a natural landscape. Since for Freud the landscape may generally symbolize woman, we can appreciate his progress through dream interpretation as a simultaneous exploration of the woman's body (see Mahony 1987b). A small sampling of that magnificent polysemy consists of an association of the dream with the navel that is suggestively intensified in the journey from Chapter Two to Seven, the respective sites of the following quotations:

Jeder Traum hat mindestens eine Stelle... gleichsam einen Nabel, durch den er mit dem Unerkanntem zusammenhängt (2/3:116fn./4:111fn.).

Dies ist dann der Nabel des Traums, die Stelle, an der er dem Unerkannten aufsitzt $(2 / 3: 530 / 5: 525)$.

Every dream has at least one place... a navel, as it were, by which it joins with the unknown. This is then the dream's navel, the place at which it straddles the unknown.

The word straddles (see Weber 1982: 75), translated by Strachey as reaches down into (S.E. 5:525), suggestively leads up to the verbal noun Unerkannten. This is derived from the verb erkennen, which, like the English know, can be used in the biblical carnal sense.

In conclusion, I shall restrict myself to several interrelated points. To start off, Loewald's insightful overview might well serve us as a gloss on Freud's own discourse:

Our scientific conceptual language - function of a specially developed, highly differentiated form of secondary-process mentation - appears to be particularly inadequate for statements about early mental functioning and about primary-process in general... The much maligned anthropomorphisms and metaphors, not infrequently used in theoretical psychoanalytic writings, in many instances serve this corrective function. They often are closer to the phenomena in question in having an evocative quality. Just because such language is more influenced by the primary-process aspects of words, by the evocative-magical qualities of language, it often constitutes a more adequate formulation of primary-process phenomena. [...] In great poetry and creative prose - in much of modern literature quite consciously - there is an interweaving of primary and secondary process by virtue of which language functions as a transitional mode encompassing both (1978: 245 and 268-269).

In the light of the above remarks, we appreciate that Freud is distinguished among psychoanalytic writers in edging toward the primary process of great creative artists.

One eminent lesson to be remembered from our reflecting on Strachey's translation is the following. In the civilized world of translation, the deliberate acts of a textual cosmetic surgeon should be considered non-gratis. If, on the other hand, the translator is not fully aware of the important yet sometimes subtle differences - professional, political, and social - between his views and those of the person translated, various ideological 
distortions are bound to creep into the secondary text. The more complex the source text is, the more the translator should be self-aware of his own different positions and their contaminatory potential. Those contaminations range in their occurrence from phonological and morphological features to the larger patterns of discourse.

Perhaps, then, the time has come not just to recognize the non-canonical status of Strachey's translation but to attempt some psychoanalysis of its defensive aspects and limitations. In several publications Ornston has skilfully demonstrated that the patient and analyst whom Freud lexically joined, Strachey has put asunder by using different words for the patient and for the analyst; such a practice qualifies as undoing. And for another thing, by repeatedly stripping the original text of the affect in its lexicality, Strachey's translation is a manifestation of defensive isolation. What is at stake for us here is not only how to read Freud but also how to read Strachey. If Freud's theory has been deformed by the translation, so also has the English reader's sentient encounter with that theory. The Gesammelte Werke, with its marked quality of affect and person, affords a different intrapsychic and interpsychic experience in reading Freud. The object relations are different (see Ornston 1982, 1985).

My last thought is that a psychoanalytic translation, in its ideal form, should be distinct from any other translation. It should identify in footnotes meanings of words in the original text that might have escaped the conscious awareness of the author. I am aware that such a notational enterprise about the unconscious is rather risky and at any event should be carried out quite selectively. It will suffice to mention a pair of examples. In his article "Fetishism" (1927), Freud talks of one patient whose disavowal of female castration was linked up with the memory of a fig-leaf (Feigenblatt, 14:316/21:157); yet Freud does not state the pertinent fact that in Viennese dialect Feign was a term for vagina (see, for example, Stekel 1959: 195).

A more assuring and sustained example is to be found in the case history of the Wolf Man. The informed reader recalls that although Freud gives several historical explanations for the patient's dream, the one receiving the most elaborate treatment is the reconstructed primal scene and its coitus a tergo. In the course of proposing his fantastical reconstruction, Freud uses the word überzeugen (convince) with exceptional frequency - an indication that he was embroiled in persuasive discourse with both his patient and his reader. But more than that: insofar as the root of überzeugen means both to procreate and to witness (the dual activities of the primal scene itself), the very frequency of the word by Freud suggests that his case history was invaded by his own unconscious derivatives (see Mahony 1984: 99ff.). If such unconscious derivatives tend to subvert Freud's original text, they also confirm his psychoanalytic tenet about the interminability of one's own analysis. The siren call of the inexhaustible unconscious lures every psychoanalyst, monolingual or not, into being both translator and traitor.

Notes

1. From this position of relativity and facilitation, Grubrich-Simitis seems to go on to adopt the Sapir-Whorf hypothesis:

Under the motto 'structure versus process' Strachey is reproached with having rendered Freud's thinking in a more static, more conceptual and would-be more precise form than the original, and thereby with falsifying it. It is well worth considering whether these critics have perhaps not paid enough attention to the differences in the basic grammatical structures of German and English - differences nowadays being systemically studied in 'contrastive linguistics,' Freud had a good mastery of English. With his language genius he could have been sufficiently aware of these insurmountable differences to have approved of Strachey's manner of translating (p. 290, my italics).

In this passage Grubrich-Simitis is talking about more than the ultimate infidelity of any translation; she is inclining to consign mentational experiences to different linguistic reserves. 
2. As in the present case, henceforth the first figures refer to the text in the Gesammelte Werke, and the second to the Standard Edition. And unless otherwise specified, all translations of Freud's works in the main body of my paper will be mine.

\section{REFERENCES}

BETTELHEIM, B. (1983): Freud and Man's Soul, New York, Alfred Knopf.

FREUD, S. (1960): Gesammelte Werke, 18 vols, Frankfurt a/M, Fischer Verlag [(1953-1954): The standard edition of the complete psychological works of Sigmund Freud, J. Strachey, Ed. and tr., 24 vols., London, Hogarth Press.] All the following references to the G.W. and S.E. will be by volume and page.

FREUD, S. (1894-1895): "Studien über Hysterie", G.W. 1: 77-312 ("Studies on Hysteria", S.E. 2).

FREUD, S. (1900): "Die Traumdeutung", G.W. 2/3 ("The Interpretation of Dreams", S.E. 4 \& 5).

FREUD, S. (1907): "Der Wahn und die Träume in W. Jensens Gradiva", Vienna. Heller (G.W. 7: 31-125; S.E. 9: 7-95).

FREUD, S. (1914): "Der Moses des Michelangelo", G.W. 10: 171-201 and 14: 321-322 ("The Moses of Michelangelo", S.E. 13: 211-238).

FREUD, S. (1915): "Triebe und Triebschicksale", G.W. 10: 210-232 ("Instincts and their Vicissitudes", S.E., 14: $117-140)$.

FREUD, S. (1915-1917): "Vorlesungen zur Einführung in die Psychoanalyse", G.W., 11 ("Introductory Lectures on Psychoanalysis", S.E., 15-16).

FREUD, S. (1920): "Jenseits des Lustprinzips", G.W., 13: 3-69 ("Beyond the Pleasure Principle", S.E., 18: 7-64).

FREUD, S. (1923): "Das Ich und das Es", G.W., 13: 237-289 ("The Ego and the id", S.E., 19: 12-66).

FREUD, S. (1927): "Fetischismus", G.W., 14: 311-317 ("Fetishism", S.E., 21: 156-157).

FREUD, S. (1933): "Neue Folge der Vorlesungen zur Einführung in die Psychoanalyse", G.W., 15 "New Introductory Lectures on Psychoanalysis", S.E., 22: 5-182).

FREUD, S. (1937): "Die endliche und die unendliche Analyse", G.W., 17: 55-59 ("Analysis Terminable and Interminable", S.E., 23: 216-253).

GIOVACCHINI, P. (1982): A Clinician's Guide to Reading Freud, New York, Jason Aronson.

GRUBRICH-SIMITIS, I. (1986): "Reflections on Sigmund Freud's Relationship to the German Language and to Some German-speaking Authors of the Enlightenment", Inter. J. Psychoanal., 67:287-294.

HOLT, R. (1872): "Freud's Mechanistic and Humanistic Images of Man", Psychoanalysis and Contemporary Science, 1: 3-24.

HOLT, R. (1978): "Ideological and Thematic Conflicts in the Structure of Freud's Thought", in The Human Mind Revisited: Essays in Honor of Karl A. Menninger, S. Smith (Ed.), N.Y., International Universities Press.

JONES, E. (1955): The Life and Work of Sigmund Freud, Vol. 2, New York, Basic Books.

LOEWALD, H. (1978): "Primary Process", in Psychoanalysis and Language, J. Smith (Ed.), New Haven, Yale University Press.

LOEWALD, H. (1980): Papers on Psychoanalysis, New Haven, Yale University Press.

MAHONY, P. (1984): Cries of the Wolf Man, New York, International University Press.

LOEWALD, H. (1987): Freud as a Writer, revised and enlarged second edition, New Haven, Yale University Press.

MALBANC, A. (1968): Stylistique comparée du français et de l'allemand, Paris, Didier.

NUNBERG, H. and Ed. FEDERN (Eds.) (1962): Minutes of the Vienna Psychoanalytic Society, Vol. 1 , New York, International Universities Press.

ORNSTON, D. (1982): "Strachey's Influence", Internat. J. Psychoanal., 63: 409-426.

ORNSTON, D. (1985): "Freud's Conception is Different from Strachey's", J. Amer. Psychoanal. Assn., 33: 337-370.

POLLAK-CORNILLOT, M. (1986): "Freud traducteur : une contribution à la traduction de ses propres ceuvres", Rev. franç. Psychanal., 50: 1235-1246.

POPPER, K. (1965): The Logic of Scientific Discovery, New York, Harper Row.

RICOEUR, P. (1965): De l'interprétation : essai sur Freud, Paris, Éditions du Seuil.

SCHAFER, R. (1976): A New Language for Psychoanalysis, New Haven, Yale U.P.

SCHOTTE, J. (1959): "Notes to his Translation of W. Muschg, "Freud als Schriftseller", also, Schotte's essay, "La lecture de 'Freud écrivain"”, Psychanalyse, 5: 51-68 and 108-124.

STEINER, R. (1986): "Clio's clinamina", Psychanalystes, 22: 91-112.

STEINER, R. (1987): "An International World-wide Trademark of Genuineness...?", Internat. Rev. Psychoanal., 14: 33-102.

STEINER, R. (1988): “'Die Weltmachtstellung des Britischen Reichs': Notes on the Term 'Standard' in the first translations of Freud", in Freud in Exile, E. Timms and N. Segal (Eds.), New Haven, Yale University Press. 
WEBER, S. (1982): The Legend of Freud, Minneapolis, University of Minneapolis Press.

WILSON, E. (1987): "Did Strachey invent Freud?", Internat. Rev. Psycho-Anal., 14: 299-316.

WHORF, B. (1942): "Language, Mind, and Reality", in Language. Thought, and Reality, J. Carroll (Ed.),

Cambridge Mass., M.I.T. Press, 1956, pp. 246-270. 